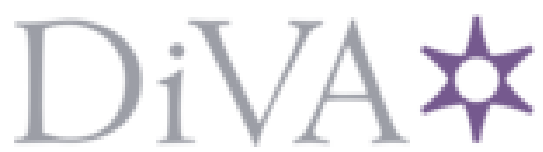

http://www.diva-portal.org

This is the published version of a paper published in .

Citation for the original published paper (version of record):

Urciuoli, L., Hintsa, J. (2018)

Improving supply chain risk management -can additional data help?

Int. J. Logistics Systems and Management, 30(2): 195-224

Access to the published version may require subscription.

N.B. When citing this work, cite the original published paper.

Permanent link to this version:

http://urn.kb.se/resolve?urn=urn:nbn:se:kth:diva-227939 


\title{
Improving supply chain risk management - can additional data help?
}

\section{Luca Urciuoli*}

MIT International Logistics Program, Zaragoza Logistics Center,

Zaragoza, Spain

Email: luca.urciuoli@gmail.com

*Corresponding author

\section{Juha Hintsa}

Cross-border Research Association, Lausanne, Switzerland

and

Department of Operations,

HEC Université de Lausanne,

Lausanne, Switzerland

Email: handhausen@gmail.com

\begin{abstract}
The recent large number of catastrophic events, such as terrorist attacks, natural disasters and pandemics, has drawn attention to the vulnerability of supply chains and the capability of IT system to monitor, predict and counteract adverse events. Experts agree that visibility and information sharing are fundamental tools to enhance the management of supply chain risks. Hence, by means of field studies conducted with seven companies, this study aims to shed more light upon how information sharing can improve supply chain risk management. As a result, the analysed companies showed great differences in their wishes for how to develop information sharing in the supply chain. Some respondents had clear visions for sophisticated, automated systems, whereas others expressed no wishes at all.
\end{abstract}

Keywords: supply chain risk management; information systems; information and communication technology; information exchange.

Reference to this paper should be made as follows: Urciuoli, L. and Hintsa, J. (2018) 'Improving supply chain risk management - can additional data help?', Int. J. Logistics Systems and Management, Vol. 30, No. 2, pp.195-224.

Biographical notes: Luca Urciuoli is an Associate Professor in the MIT International Logistics Program at the Zaragoza Logistics Center in Spain, where he teaches and performs research in supply chain network design, supply chain risk, and security management. He holds an MSc degree in Industrial Engineering from Chalmers University of Technology in Gothenburg, Sweden, and a Doctorate in Transportation Security from the Engineering University of Lund, Sweden. He has been working at the research unit of the Volvo Group as a Project Manager developing on-board transport and telematics services. He also led the research of the Cross-Border Research Association in Switzerland and collaborated in several FP7 research and consultancy projects, with a focus 
on topics like e-Customs, trade facilitation, supply chain security, waste security, and postal security. $\mathrm{He}$ is also an editorial board member for the Journal of Transportation Security, and he has published his research in several scientific and practitioner journals.

Juha Hintsa is a Senior Researcher, Lecturer and Consultant in Supply Chain Security and Global Trade Facilitation. He has professional background in consumer goods, steel industry, and software sector - before shifting to his current field of interest in summer 2001. He has a Master's in Engineering from Helsinki University of Technology and a $\mathrm{PhD}$ in Management from HEC University of Lausanne. In 2005 he founded Cross-Border Research Association, CBRA, as an independent research institute to focus on supply chain security and trade facilitation research - acting as the Executive Director and a board member. He has published over 55 articles in academic and practitioner journals and proceedings, as well as in governmental and industry reports. He is an Associate Editor for the Journal of Transportation Security and editorial board member for the World Customs Journal, as well as an advisory group member for the World Customs Organization's PICARD program.

\section{Introduction}

The recent large number of catastrophic events, such as natural disasters, terror attacks, pandemics, etc. has drawn attention to the vulnerability of supply chains (Jüttner, 2005). Vulnerability means that supply chains are susceptible for disruptions, i.e. interruptions in business operations, resulting in undesirable consequences such as delayed deliveries or lost sales (Svensson, 2002). For example, the earthquake that hit Taiwan in September 1999 had a severe impact on the personal computer industry worldwide $(10 \%$ of the world's computer chips and $80 \%$ of the world's motherboards were produced in Taiwan). Lost revenues resulting from the production shut-down were estimated to over 200 million dollars (McGillivray, 2000).

It has been claimed that changing business trends are making supply chains more vulnerable. For instance, globalisation, specialisation, complexity, and lean processes have been indicated as drivers of risks (Pfohl et al., 2010; Schwab, 2012). These trends make supply chains more complex and consequently decrease the capability of managers to control them properly (Harland et al., 2003; Jüttner et al., 2003). Consequently, interest in supply chain risk management has increased rapidly since the beginning of 21 st century, and the growing importance for supply chain risk management has also been visible in corporations (Peck, 2006). In a global survey to supply chain managers, over $90 \%$ of the respondents reported that supply chain and transportation risk management has received greater priority in the last five years. External disruption to supply chains and transportation networks often result in falling stock prices and cause reputational implications (Schwab, 2012). Hence, the concern for supply chain and transportation disruptions is also shifting from operational managers to top management, including c-suite level leadership and corporate boards.

Experts agree that visibility and information sharing are fundamental tools to enhance the management of supply chain risks. Monitoring some specific data as well as having better visibility on operations and processes may help decision makers in understanding 
the behaviour of supply chains, and consequently learn when risks could strike and what mitigation measures should be adopted. Examining previous research, we realise that this area is still under explored. Sanchez Rodrigues et al. (2008) point out that "little research has been undertaken on the impact of uncertainties on transport in the context of collaborative supply chain management". Similarly, Barratt and Oke (2007) claim that the link between visibility and supply chain risk management is still too normative. Hence, more studies based on empirical data are needed. For this reason, the research question of this paper is the following:

RQ How can information sharing improve supply chain risk management?

Multiple case studies have been used in order to enhance understanding about the role of visibility in managing inbound logistics risks as well as the role of information sharing in managing these risks. Data was collected by means of a questionnaire sent to managers in selected companies.

The structure of this article is the following: first of all, relevant literature screened is presented in the next section. The literature is structured under main topics like supply chain risk management, and information sharing. Next, the methodology is expounded. Thereafter, the results from the case studies are analysed. Finally, results are discussed and conclusions, including recommendations, are given at the end.

\section{Literature review}

\subsection{Supply chain management}

The management of supply chains embraces several approaches and practices that aim to integrate the supply chain partners, like suppliers, manufacturers, distributors and retailers, within a single business model (Tatoglu et al., 2016). Supply chain management has the primary objective to eliminate inefficiencies in processes, assets, inventories, while improving customer demand forecasts, avoiding stock outs and customers' satisfaction. Examples of supply chain management practices include strategic supplier partnership, customer relationship management, inventory optimisation, information sharing and quality, adoption of lean practices and postponement (Mobin and Roshani, 2016; Mousavi et al., 2016; Mousavi and Pasandideh, 2011; Li et al., 2005).

Managing a supply chain implies maximising or optimising its performance, in terms of the ability to provide to customers the right quantities, at the right time and place with the right quality (Dwayne Whitten et al., 2012). Hence, the concept of improved customer satisfaction through enhanced product quality and experience is central (Hoyt and Huq, 2000). However, maintaining production and services costs low cannot be neglected (Dwayne Whitten et al., 2012). This is necessary in order to maximise revenues from products while building capabilities for competitive advantage. Other research has highlighted that high performing supply chains should be able to adapt to dynamic business environments as well as should be enough flexible and agile to withstand unexpected events and disruptions (Vanderhaeghe and Treville, 2003; Sheffi and Rice, 2005). Supply chain performance depends upon its level of agility, adaptability and alignment with supply chain partners (Lee, 2004). Building a resilient enterprise means increasing the competitiveness and flexibility of the company (Sheffi and Rice, 2005). Improved performance of supply chains is also frequently associated to ICT technologies 
and advanced systems. These systems, e.g. advanced planning scheduling, material resource planning, vendor management inventory etc., can enhance monitoring and control capabilities and thereby improve overall quality, speed and flexibility (Lee and Whang, 2005; Gunasekaran et al., 2004; Sadeghi et al., 2013).

\subsection{Supply chain risk management}

When discussing supply chain risk management, it is first important to understand what is meant with supply chain risk. In general, risk is defined as an unfavourable event with a certain probability and impact, but this classical view of risk is seen as limited by several authors. Firstly, it is pointed out that risk taking is not automatically negative and does not always relate to losses (Pfohl et al., 2010). The opposite side of risk can be seen as opportunities or chances from which the company can take advantage. Peck (2006) on the other hand, claim that there seldom is an upside for risk in the supply chain context. Secondly, when discussing the probability and impact of risk, there is a difference between risk that occurs as a distribution and risk that occurs as a discrete event (Viswanadham and Gaonkar, 2008). One parameter within the supply chain, such as cost, demand or lead-time, can vary around an average value, whereas events such as natural disasters and accidents either occur or do not occur in a binary way. The classic definition of risk does neither take into account uncertainty. Probability and impact define risk as something quantifiable, something that is known and can be modelled. Uncertainty, on the other hand, occurs when the neither the outcome nor the probability of an event can be estimated on beforehand (Sanchez Rodrigues et al., 2008). Also Schwab (2012) points out that even though it is possible to identify likely types of disruption, the precise nature of these and their impact on global supply chain and transport networks are hard to predict. Thirdly, increased lead times and physical distances have led to lesser control of the supply chain, making the speed and frequency of risk important factors to consider as well. Speed of risk is associated with how fast a threat and a loss escalates, and how rapidly it can be detected, whereas frequency deals with how often similar events happen. Practitioners also identify the interrelationship and linkage between separate risks as an important aspect of supply chain risk, especially in global supply chains and networks (Manuj and Mentzer, 2008). Fourthly, when discussing supply chain risk, and risk in general, it is also important to understand the difference between risks as source and risk as a consequence (Pfohl et al., 2010, Jüttner et al., 2003). Risk as a source is associated with the event or hazard, i.e. the variables in the environment, supply chain and organisation that impact the performance of the supply chain, whereas risk as a consequence is focused on the actual outcomes from these events.

Finally, supply chain risk can also be defined in totally different manner. Viswanadham and Gaonkar (2008) discuss supply chain risk in terms of supply chain exceptions. They define an exception using the 'seven R's' definition for the purpose of logistics, which is "to ensure the availability of the right product, in the right quantity, in the right condition, at the right place, at the right time, at the right cost, for the right customer". An exception occurs whenever one of these requirements is not met. This approach to risk also agrees with how many practitioners choose to define supply chain risk (Manuj and Mentzer, 2008). Defining risk through exceptions also highlights an important observation pointed out by Peck (2006), which is that transportation and infrastructure risks often are left out when considering supply chain risk. 
When it comes to categorising supply chain risk, a multitude of different manners exist (Venkatesh et al., 2015). Some authors categorise supply chain risk according to the proximity of the risk source to the focal company, in other words distinguish between internal risk, network risk and external risk (Peck, 2006; Pfohl et al., 2010; Lockamy and McCormack, 2009; Viswanadham and Gaonkar, 2008). Others categorise supply chain risk in relation to the flows in the supply chain. Pfohl et al. (2010) address the traditional flows of goods, information and money, whereas demand and supply risks are identified by a large group of authors (Johnson, 2001; Jüttner, 2005; Manuj and Mentzer, 2008; Wagner and Bode, 2006). A third group of authors approach supply chain risk from a business management perspective, identifying operational disturbances, tactical disruptions and strategic uncertainties (Jüttner et al., 2003). A fourth group of authors discuss supply chain risks according to the severity of impacts, and identify three groups of risks: deviations, where one parameter such as cost or demand change, disruptions, where the structures of the supply chain is radically transformed, and disasters, where the whole supply network is temporarily shut down (Viswanadham and Gaonkar, 2008).

As can be seen from the discussion, supply chain risk is a very multifaceted concept with a multiple of approaches. Indeed, Sodhi et al. (2012) in an extensive study on perspective on supply chain risk management, identified the lack of shared understanding of supply chain risk both in the academic society and among practitioners.

Moving on to supply chain risk management makes the discussion no easier as several different definitions on supply chain risk management coexist. Jüttner et al. (2003) define supply chain risk management as "the identification and management of risks for the supply chain, through a coordinated approach amongst supply chain members, to reduce supply chain vulnerability". This definition coincides quite well with the aspects of supply chain risk management that most authors identify. Most definitions of supply chain risk management include the following aspects (Manuj and Mentzer, 2008, Jüttner, 2005, Pfohl et al., 2010):

1 understanding the risk, through identification, evaluation or assessment of risks

2 acting upon the risk, through management, handling, treatment or mitigation of risks, or through implementation of strategies

3 a structured, systematic, and disciplined approach

4 a coordinated and collaborative approach amongst supply chain partners.

When discussing supply chain risk management, Harland et al. (2003) point out that focus has long been only on supply and demand risk management and little on networks. Current business trends such as globalisation, outsourcing and product complexity have made supply chains evolve to complex and dynamic networks with an increasing degree of interconnectedness both between supply chain parties and supply chain risks, which should be taken into account in supply chain risk management (Harland et al., 2003; Pfohl et al., 2010; Chopra and Sodhi, 2012). Also Pfohl et al. (2010) recognise that the potential 'domino effect' of risks needs to be analysed with regard to all partners in the supply chain.

A particular feature of supply chain risk management highlighted by several authors is the collaborative aspect. Jüttner (2005) point out that in order to reduce supply chain vulnerability as a whole it needs to be approached in a coordinated manner between supply chain members. A single actor in the supply chain seldom is able to take the 
strategic and operational decisions required to reduce the vulnerability of the supply chain (Schwab, 2012). Indeed, mutual goal setting and planning is necessary across the entire supply chain as mutual identifying and communicating of problems is needed to reduce information asymmetries (Pfohl et al., 2010).

Blome and Schoenherr (2011) recognise that effective supply chain risk management requires a systematic approach, and suggest a four step approach with risk identification, risk analysis, risk mitigation/acceptance and risk monitoring. Harland et al. (2003) used iterative case studies to develop a supply network risk tool with the steps of mapping the supply network, identifying, assessing and managing risk, and finally forming and evaluating collaborative supply network strategies.

Several other authors suggest to a large extent similar processes for supply chain risk management. In a literature review based on a large number of papers from the field Sodhi et al. (2012) synthesise the supply chain risk management process elements to be identification of risk, assessment of risk, mitigation of risk, and responsiveness to risk (Figure 1).

Figure 1 The steps in the risk management process

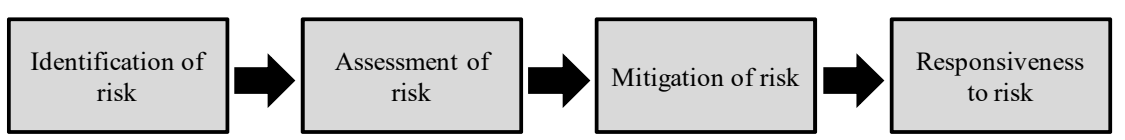

Source: Sodhi et al. (2012)

The first step in the risk management process, identification of risk, includes collecting and documenting all potential risks that can affect the organisation (Urciuoli, 2016). Some authors suggest that this step should be preceded by establishment of the context, i.e. identifying relevant stakeholders and processes in the supply chain (Urciuoli and Hintsa, 2016). Assessment of risk, the second step, is about evaluating the likelihood and the impact of the risks. Some authors also point out the step of evaluating risks, i.e. deciding which risks should be acted upon and which risks should simply be accepted. Mitigation of risk, the third step, includes preventive risk strategies, i.e. actions taken in order to reduce the likelihood and/or impact of the risk. As companies cannot eliminate all risk, the final step, responsiveness to risk, is about how to respond when a risk event realises (Sodhi et al., 2012).

According to Blome and Schoenherr (2011) the different steps in the risk management processes are interlinked, which means that a successful risk management requires that all steps in the supply chain risk management process are carried out. The International Organization for Standardization points out that the process for managing risk should be preceded by principles for managing risk and a framework for managing risk. Jüttner (2005) also talks about 'philosophy' (in addition to principles) as the highest conceptual level of supply chain risk management.

\subsection{Information sharing in supply chains}

As follows from the reported need for increased supply chain integration and information sharing, several authors report a positive relationship between these concepts and 
performance. Supply chain as well as information sharing has indeed been found to improve supply chain performance (Koçoğlu et al., 2011; Flynn et al., 2010; Frohlich and Westbrook, 2001; Jayaram and Tan, 2010). What should be particularly noted is the findings of Koçoğlu et al. (2011), which present that supply chain integration has both a direct positive impact on supply chain performance, and a direct positive impact on information sharing, which in turn has a positive impact on supply chain performance, explaining the dynamics between supply chain integration, information sharing and performance.

Suggested benefits of information sharing in the supply chain include reduced supply chain cost, improved partner relationships, increased material flow, faster deliveries, improved decision making, and achievement of competitive advantage (Barratt and Oke, 2007; Koçoğlu et al., 2011). It is on the other hand suggested that increased visibility leads to benefits such as improved responsiveness, improved planning and replenishment capabilities, and improved decision making (Barratt and Oke, 2007).

But how is integration and information sharing really linked to the improved performance? Agndal and Nilsson (2008) found that the open book policy, i.e. sharing cost data between suppliers and the focal company, supported cost management decision making as well as improved the collaboration and relationship between the companies. It is suggested that system-wide information improves operational performance, but it is also noted that that "too much information may actually lead to sub-optimal performance since individuals face near-term cognitive limitations when it comes to processing information to make informed decisions" (Cantor and MacDonald, 2009). As these authors explain, visibility seems to be linked to performance through decision making.

Christopher and Lee (2004) explain the dynamics behind supply chain visibility and operational performance with what they call 'the risk spiral'. They claim that long pipelines reduce supply chain visibility, which in turn leads to a lack of confidence between supply chain partners. This lack of confidence leads to the build-up of inventory buffers, over-production, non-reliable quotes on delivery times, etc., as a way to hedge against the uncertainty, which in turn further lengthens the pipeline, which further reduces the visibility. Lack of visibility therefore leads to a less efficient supply chain. The authors suggest that only improved confidence can break the spiral and improve operational performance. Improved confidence allows information sharing among supply chain partners, which is seen as the key to improved visibility, which in turn leads to better decision making. They point out that visibility alone is not enough, but that the ability to take control of supply chain operations (i.e. ability to make decisions) and even risks is also required (Fan et al., 2016).

Other authors still find a less positive relationship between supply chain integration and information sharing, and performance. Sezen (2008) concludes in his study that supply chain design has a higher influence on supply chain performance than supply chain integration or information sharing. Jayaram and Tan (2010) have studied the relationship between supply chain integration with third party logistics providers and supply chain performance, and conclude that the supply chain integration strategy does not in itself show as a variance in performance. Also they suggest that the right level and form of integration might be more important than integration itself.

To conclude, supply chain visibility seems to be tightly related to the level of information sharing in the supply chain (Barratt and Oke, 2007). It is a state at which 
companies have more information available about what is going on in other parts of the supply chain, based on which they can make better decisions. Information sharing, visibility and improved decision making, together with an number of other collaborative activities between supply chain actors, are part of what is called supply chain integration. Supply chain integration, more specifically information sharing, requires certain enablers, such as availability of data, trust and confidence between parties, and integrative technology. Supply chain integration, on the other hand, leads to enhanced performance through improved decision making. These relationships between supply chain visibility and closely linked concepts are presented in Figure 2.

Figure 2 Relationship between visibility and closely linked concepts

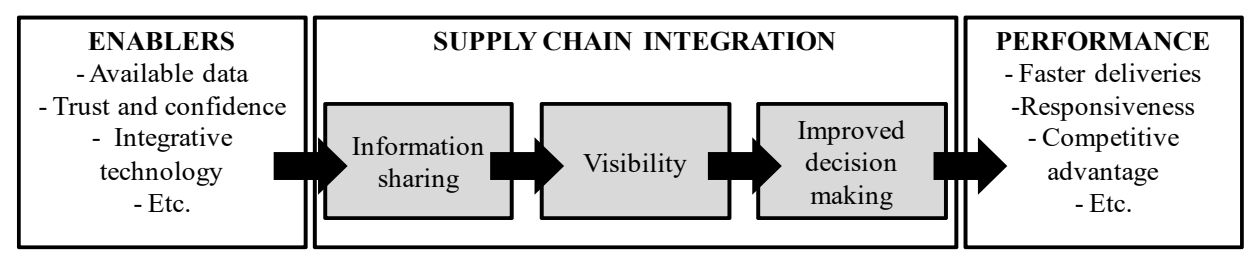

Source: Barratt and Oke (2007)

\section{Methodology}

The methodology followed in this study is based on two phases: case study research, specifically seven case companies where data was collected by means of a field study containing a questionnaire (Yin, 2014). In-depth analysis of the results by means of the technique for order of preference by similarity to ideal solution (TOPSIS) approach.

\subsection{Case study research}

Seven companies to be used in the case studies were chosen. The sample used in the study was made of targeted global supply chains based in Finland. The contacted companies were from the buying end of the supply chain, and managers were selected from the supply chain management, logistics and procurement departments. After gathering data from the seven companies, follow-up questions were sent to two of the respondents. Table 1 gives a concise description of the case companies, industry sector, turnover, goods procured, geographical coverage and position of respondents. As it can be noticed, the participating companies represent different industrial sectors, are of different size, and have supply chains that cover different parts of the world. In addition, the respondents have senior positions in the companies or directorship roles, indicating a good degree of knowledge and experience in the field.

A five-pages questionnaire was developed to identify what risks companies face in inbound operations (inbound logistics risks), what information they use for monitoring and managing these risks, and what information they share related to these risks (the questionnaire is provided as an Appendix). Before launching the study, the questionnaire was reviewed and commented by several supply chain experts, two academics, and finally tested with two companies. 
Table 1 Demographics data of participating companies and respondents

\begin{tabular}{|c|c|c|c|c|c|}
\hline Company & Industry & $\begin{array}{l}\text { Turnover } \\
\text { (MEUR) }\end{array}$ & $\begin{array}{c}\text { Goods } \\
\text { procured }\end{array}$ & $\begin{array}{c}\text { Geographical } \\
\text { coverage }\end{array}$ & Position \\
\hline MFG_1 & Manufacturing & 300 & $\begin{array}{l}\text { Paper, } \\
\text { aluminium } \\
\text { foil, plastics }\end{array}$ & Asia-Europe & $\begin{array}{l}\text { Group supply } \\
\text { chain manager }\end{array}$ \\
\hline MFG_2 & Manufacturing & 53,000 & $\begin{array}{l}\text { Aircraft parts, } \\
\text { aluminium, } \\
\text { composites }\end{array}$ & Asia-Europe & $\begin{array}{c}\text { Senior } \\
\text { manager, } \\
\text { supply chain } \\
\text { and aviation } \\
\text { security }\end{array}$ \\
\hline MFG_3 & Manufacturing & 800 & Valves & $\begin{array}{l}\text { Several global } \\
\text { trade lanes }\end{array}$ & $\begin{array}{l}\text { Purchasing } \\
\text { director }\end{array}$ \\
\hline HIGH_TECH & High tech & 39,000 & $\begin{array}{l}\text { Semi-finished } \\
\text { goods }\end{array}$ & $\begin{array}{l}\text { Asia - North } \\
\text { America }\end{array}$ & $\begin{array}{l}\text { Director, } \\
\text { customer } \\
\text { logistics }\end{array}$ \\
\hline FOOD & Food & 77 & Food products & $\begin{array}{l}\text { Several global } \\
\text { trade lanes }\end{array}$ & $\begin{array}{l}\text { Director trade } \\
\text { compliance }\end{array}$ \\
\hline ELEC & Electrical & 125 & N/A & Asia-Europe & $\begin{array}{l}\text { Procurement } \\
\text { accountant }\end{array}$ \\
\hline CHEM & Chemical & 250 & $\begin{array}{l}\text { Paints and } \\
\text { chemicals }\end{array}$ & $\begin{array}{c}\text { Asia - Europe, } \\
\text { Europe - } \\
\text { Europe }\end{array}$ & $\begin{array}{l}\text { Purchase } \\
\text { manager }\end{array}$ \\
\hline
\end{tabular}

As it is challenging to make an exhaustive list of risk sources, inbound logistics risks were defined with the help of the SCOR model and the 7R's of logistics. The SCOR model defines effective supply chain management to be "all about delivering the right product in the right quantity and in the right condition with the right documentation to the right place at the right time at the right price" (Huan et al., 2004), whereas the 7R's of logistics says the aim of logistics is to "ensure the availability of the right product, in the right quantity, in the right condition, at the right place, at the right time, at the right cost, for the right customer" (Viswanadham and Gaonkar, 2008). Based on these two definitions, possible inbound logistics risks were identified as exceptions to these ideal states, including:

1 late deliveries

2 early deliveries

3 under-quantity deliveries

4 over quantity deliveries

5 wrong product deliveries

6 sub-quality deliveries

7 deliveries with damaged goods

8 deliveries to wrong place

9 actual delivery cost exceeds planned cost

10 deliveries with wrong documentation or data

11 deliveries with missing documentation or data. 
To identify the relevance of these risks the companies were asked to assess the frequency and the impact of these logistics problems on a five-point Likert scale. The companies were also asked which supply chain partners normally cause most problems. Further, to understand what information is used for monitoring and managing risks, the companies were asked to state what risk rules they use in monitoring their operations. Risk rules, in other word standard operation procedures, are used to notify the company of an emerging problem, to define when to react on a problem, and to define actions to take when a problem occurs. Supply chain visibility is a difficult and often ill-defined term; asking for risk rules and related information takes visibility to a more concrete level in showing what information the companies currently use for managing risks. To get a picture of the current state of information sharing in the supply chains, the companies were also asked directly about data elements that they receive from or share with other actors in the supply chain. Finally, to understand the role of logistics risks in overall supply chain risk the companies were asked to rank the importance of supply risks, demand risks, operational risks and environmental risks.

\subsection{Technique for order of preference by similarity to ideal solution}

TOPSIS stands for technique for order preferences by similarity to an ideal solution and it is a method that allows analysts in choosing the best alternative by ranking a set of options scored according to different criteria. The peculiarity of TOPSIS is that the identified best alternative is a compromise solution with the shortest Euclidean distance to the ideal solution (positive), and farthest from the less ideal (inferior or negative solution) (Tzeng and Huang, 2011).

Given a set of alternatives, $A=\left\{A_{k} \mid k=1, \ldots, n\right\}$, and a set of criteria, $C=\left\{C_{j} j j=1, \ldots, m\right\}$, to evaluate the alternatives, it is possible to define the performance ratings as $X=\left\{x_{k j} \mid k=1, \ldots n ; j=1, \ldots, m\right\}$. In addition, each criteria can be weighted by analysts by means of a set of weights defined as $w=\left\{w_{j} j=1, \ldots, m\right\}$ (Tzeng and Huang, 2011; Salmon et al., 2015). In this paper, the alternatives are the 11 inbound risks mentioned previously $(n=11)$, the criteria are three, i.e. the different measures estimated by the respondents, frequency, impact and risk value $(m=3)$. The weights were estimated at a later stage of the analysis and are respectively, frequency $=0.3$, impact $=0.3$, and risk $=0.4$.

Table 2 Table with information used in TOPSIS

\begin{tabular}{c}
{$\left[\begin{array}{cccc}C_{1} & C_{2} & \cdots & C_{m}\end{array}\right]$} \\
$\underset{\Xi}{\stackrel{\Xi}{\Xi}}\left[\begin{array}{c}A_{1} \\
A_{2} \\
\vdots \\
A_{n} \\
W\end{array}\right] \quad\left[\begin{array}{cccc}x_{11} & x_{12} & \cdots & x_{1 m} \\
x_{21} & x_{22} & \cdots & x_{2 m} \\
\cdots & \cdots & \cdots & \cdots \\
x_{n 1} & x_{n 2} & \cdots & x_{n m} \\
w_{1} & w_{2} & \cdots & w_{m}\end{array}\right]$ \\
\hline
\end{tabular}

Notes: $\mathrm{A}=$ alternatives $\mathrm{C}=$ criteria; $\mathrm{W}=$ weights; $\mathrm{X}=$ performance ratings 
With the data in the tables, the first step is to calculate normalised rankings, as according to the following:

$$
r_{k j}=\frac{x_{k j}}{\sqrt{\sum_{k=1}^{n} x_{k j}^{2}}}, k=1, \ldots, n ; j=1, \ldots, m
$$

Next the normalised rank is weighted, and the positive (PIS) and negative ideal points (NIS) are derived (Salmon et al., 2015):

$$
\begin{aligned}
v_{k j} & =w_{j} r_{k j}(x), k=1, \ldots, n ; j=1, \ldots, m \\
P I S & =A^{+}=\left\{v_{1}^{+}(x), v_{2}^{+}(x), \ldots, v_{m}^{+}(x)\right\} \\
& =\left\{\left(\max _{k} v_{k j} \mid j \in J_{1}\right),\left(\min _{k} v_{k j} \mid j \in J_{2}\right) \mid k=1, \ldots n\right\} \\
N I S & =A^{-}=\left\{v_{1}^{-}(x), v_{2}^{-}(x), \ldots, v_{m}^{-}(x)\right\} \\
& =\left\{\left(\min _{k} v_{k j} \mid j \in J_{1}\right),\left(\max _{k} v_{k j} \mid j \in J_{2}\right) \mid k=1, \ldots n\right\}
\end{aligned}
$$

Where $J_{1}$ and $J_{2}$ are respectively attributes associated to benefits and costs. Hence, in the positive ideal solution, benefits need to be maximised and costs minimised; while, in the negative ideal solution, the benefits need to be minimised and costs maximised. This depends on the goals of the model and the type of attributes chosen for the analysis.

Finally, two separation values are calculated as the Euclidean distance between the weighted normalised ratings:

$$
\begin{aligned}
D_{k}^{+} & =\sqrt{\sum_{j=1}^{m}\left[v_{k j}(x)-v_{j}^{+}(x)\right]^{2}, k=1, \ldots, n} \\
D_{k}^{-} & =\sqrt{\sum_{j=1}^{m}\left[v_{k j}(x)-v_{j}^{-}(x)\right]^{2}, k=1, \ldots, n}
\end{aligned}
$$

Given the two separation values, a final ranking factor is calculated as:

$$
C_{k}^{+}=\frac{D_{k}^{-}}{D_{k}^{+}+D_{k}^{-}}, \forall k=1, \ldots, n ; C_{k}^{+} \in[0,1]
$$

\section{Case study findings}

The results regarding the frequency and impact of inbound logistics risks are presented in Figure 3 (sorted by frequency), Figure 4 (sorted by impact), Figure 5 (total risk) and Figure 6 (risk matrix). As shown in the figures, late deliveries, wrong information and exceeding costs were identified as the most frequent problems (Figure 3), whereas sub-quality deliveries, wrong product deliveries and deliveries with damaged goods were identified the problems with the highest impact (Figure 4). 


\subsection{Risk analysis}

The most important problem, when defining overall risk as frequency times impact, is late deliveries (Figure 3; Figure 5). Late deliveries are in fact the only risk that ranked high on these both criteria. Also worth noting is that all companies, except for the food company, ranked late deliveries as their most important problem. The food company ranked late deliveries as their second most important problem, and clarified that:

"The greatest risks we face has to do with food safety/food defense issues
rather than the more common issues arising from logistics snags. This isn't to
suggest that late shipments or shipments to wrong ports with wrong products
aren't important but that the potential impact of an unsafe or poisonous product
being imported and consumed are just too costly to calculate."

Other inbound logistics risks that ranked high were sub-quality deliveries, deliveries with damaged goods and wrong product deliveries. Worth noting is that these risks have a high impact but are not very frequent (Figure 4). Early deliveries and over quantity deliveries ranked neither as frequent nor with a high impact (Figure 4 and Figure 5).

When asked about which supply chain partner cause possible problems, the seller was the most often mentioned actor. All companies agreed on the seller being the party causing under/over quantity deliveries, wrong product deliveries and sub-quality deliveries. For deliveries with missing or wrong information all companies mentioned the seller, but one of the companies also brought up the freight forwarder. The freight forwarder, sea terminal operator and other transportation parties were, in addition to the seller, also mentioned for late/early deliveries and deliveries with damaged goods.

To understand the role of logistics risks in supply chain management, the companies were asked to rank the importance of supply, demand, operational and environmental risks. For all companies, supply risk ranked first or second, whereas the demand and operational risks ranked quite equally in the middle on average. There was still a wide spread in the answers for demand risk between the companies; two of the companies ranked it as their most important risk whereas two of the companies ranked it as their least important risk. For the rest of the companies, demand risk ranked in the middle. Operational risks, on the other hand, ranked second or third for all companies, whereas environmental risks ranked low for all companies.

Figure 3 Frequency and impact of inbound logistics risks (sorted by frequency) assessed by the respondents on a qualitative scale from 1 to 5

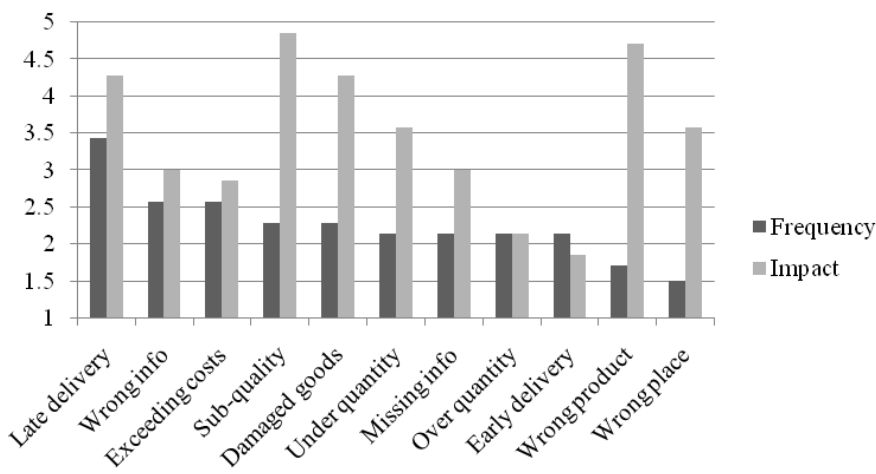


Figure 4 Frequency and impacts of inbound logistics risks (sorted by impact) assessed by the respondents on a five points Likert scale

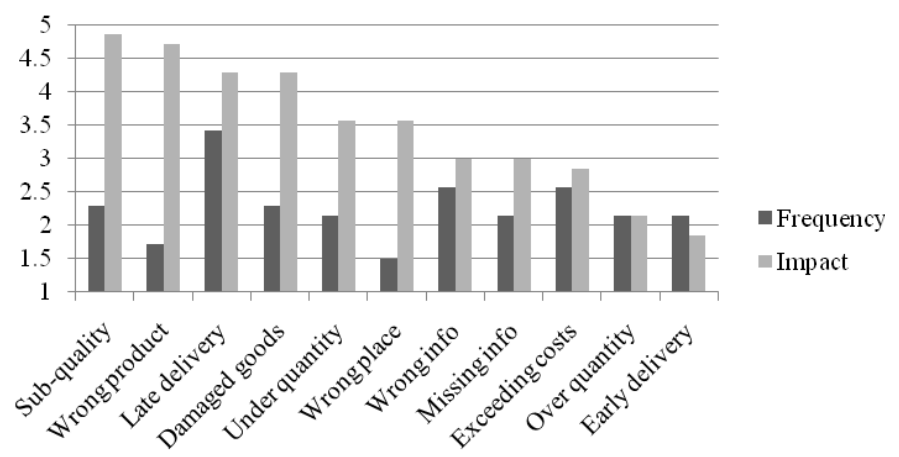

Figure 5 Total risk (as frequency $\times$ impact) of inbound logistics risk

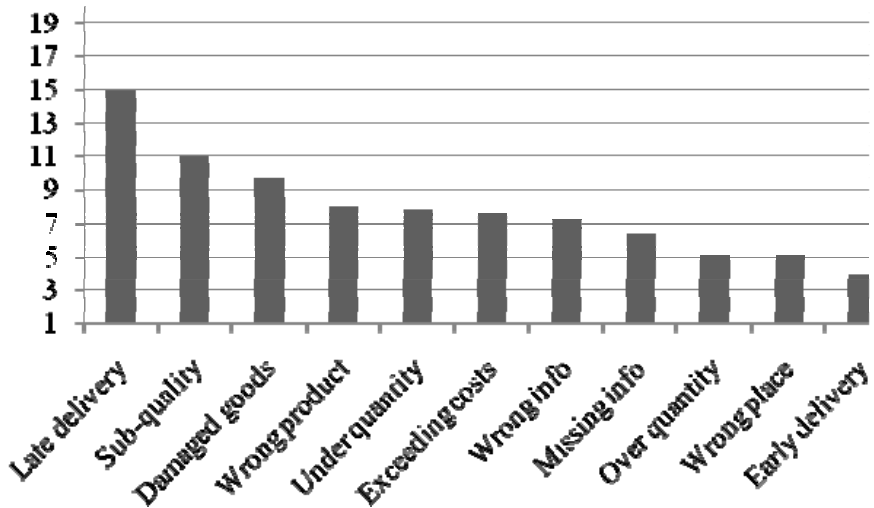

Figure 6 Risk matrix for inbound logistics risks

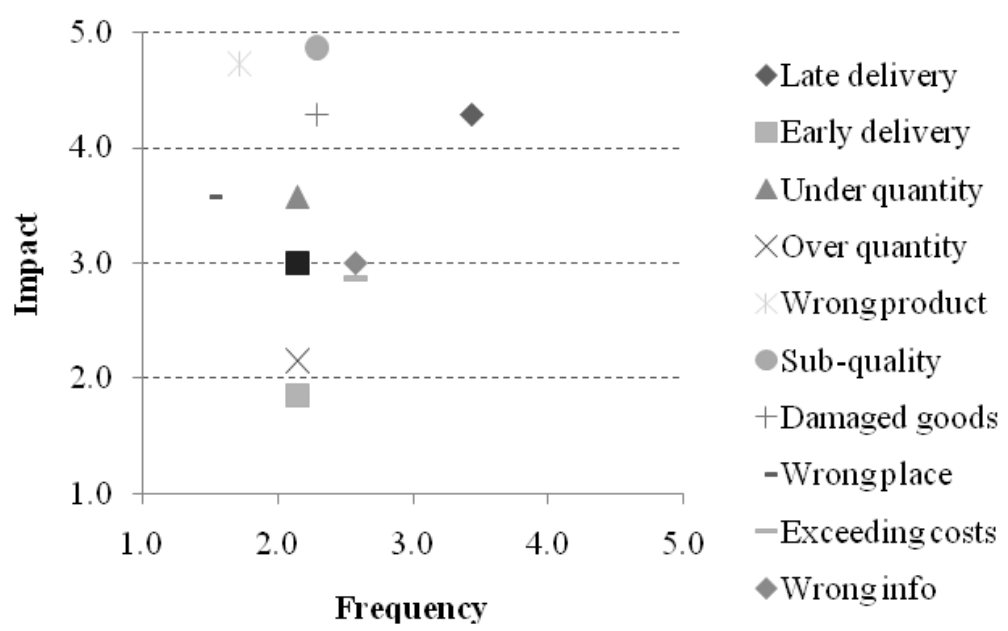




\subsection{Information to be shared}

Data about the current state of visibility was collected both through the risk rules the companies use for monitoring their deliveries, and by asking directly about what data the companies receive or share related to their deliveries. As the companies were asked to answers these parts of the questionnaire based on their three most important problems, this part does not cover all problems equally but concentrates especially on late deliveries, which all companies ranked among their most important problems. A summary of all data elements used for monitoring logistics risks is presented in Table 3, and a more detailed, company-wise summary of data elements used for managing late deliveries is presented in Table 4.

In general, the current state of visibility is quite limited to the traditional view of the supply chain, which means information sharing mainly takes place between the buyer and the seller. As presented in Table 3, much of the information currently used for monitoring deliveries comes from the supplier. Exceptions to this still occur, especially regarding the monitoring of late deliveries.

Information received from the supplier includes order confirmation data, order follow-up data, and supplier quality control data, which are used to monitor that the deliveries are on time, in the right quality and in the right quantity. In addition, the respondents reported that they use time stamps and other data related to the flow of goods from logistics parties to monitor late (or early) deliveries. It is also worth noting that the respondents use an important part of in-house information, such as data on outstanding orders and quality control data from testing of arriving goods, to monitor their inbound logistics. The importance of following inventory levels was also pointed out by a couple of the respondents.

Regarding future possibilities, the respondents desired improved information sharing with suppliers especially when it comes to inventory statuses and quality information. The companies would also like to have better and more up-to-date information on location and status of deliveries from transportation and logistics parties. Some respondents also wish for improved information sharing with governmental actors, especially regarding accreditation of suppliers and submission of transportation documents. All this speaks for a need for improved information sharing and visibility in the supply chain, both regarding inbound logistics and supply chain management in general. In addition, several respondents mention that they would like to have automatically updated data and automated alerts for deviations or problems, indicating that there is a need for more interlinked technology solutions, either through EDI/XML or over the Internet. For the moment much of the data is shared via phone or e-mail, or collected manually from a website.

When it comes to late deliveries, all companies reported that they track or monitor their deliveries on the route from the seller to the buyer at least at some points in the supply chain, which means all companies have some sort of visibility to their deliveries. Six of the companies reported that they receive order statuses or shipping information via e-mail or phone, or check for order statuses manually on a website, whereas only one of the companies gets automatic updates into their management system. In most of the companies, information sharing is thus currently not automated and the information available necessary not up-to-date. This indicates that there could be room for improved real time information sharing in the supply chain. 
Table 3 Information used by buying companies for managing inbound logistics risks

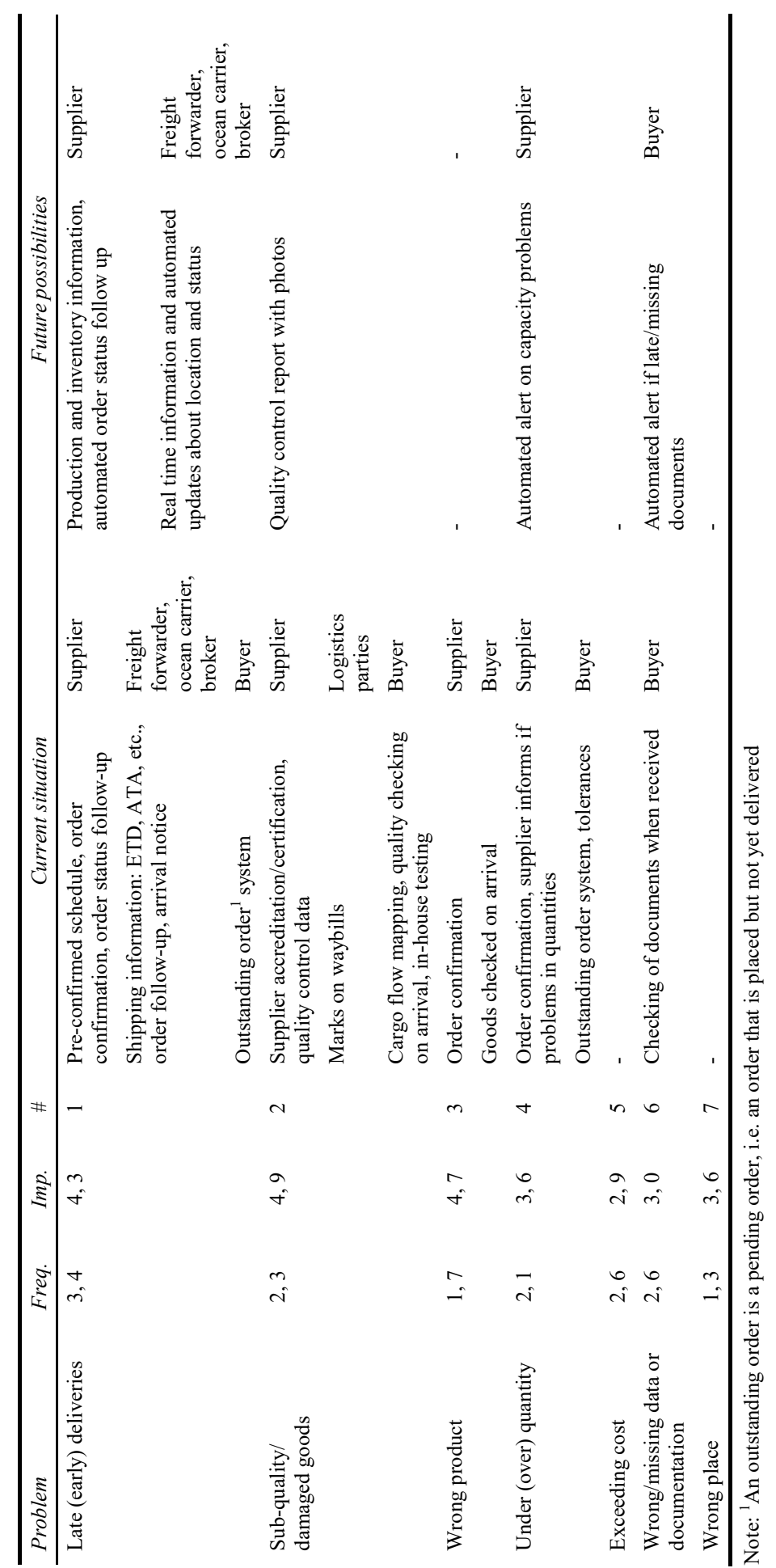


Table 4 Current situation of and future possibilities for visibility in managing late deliveries

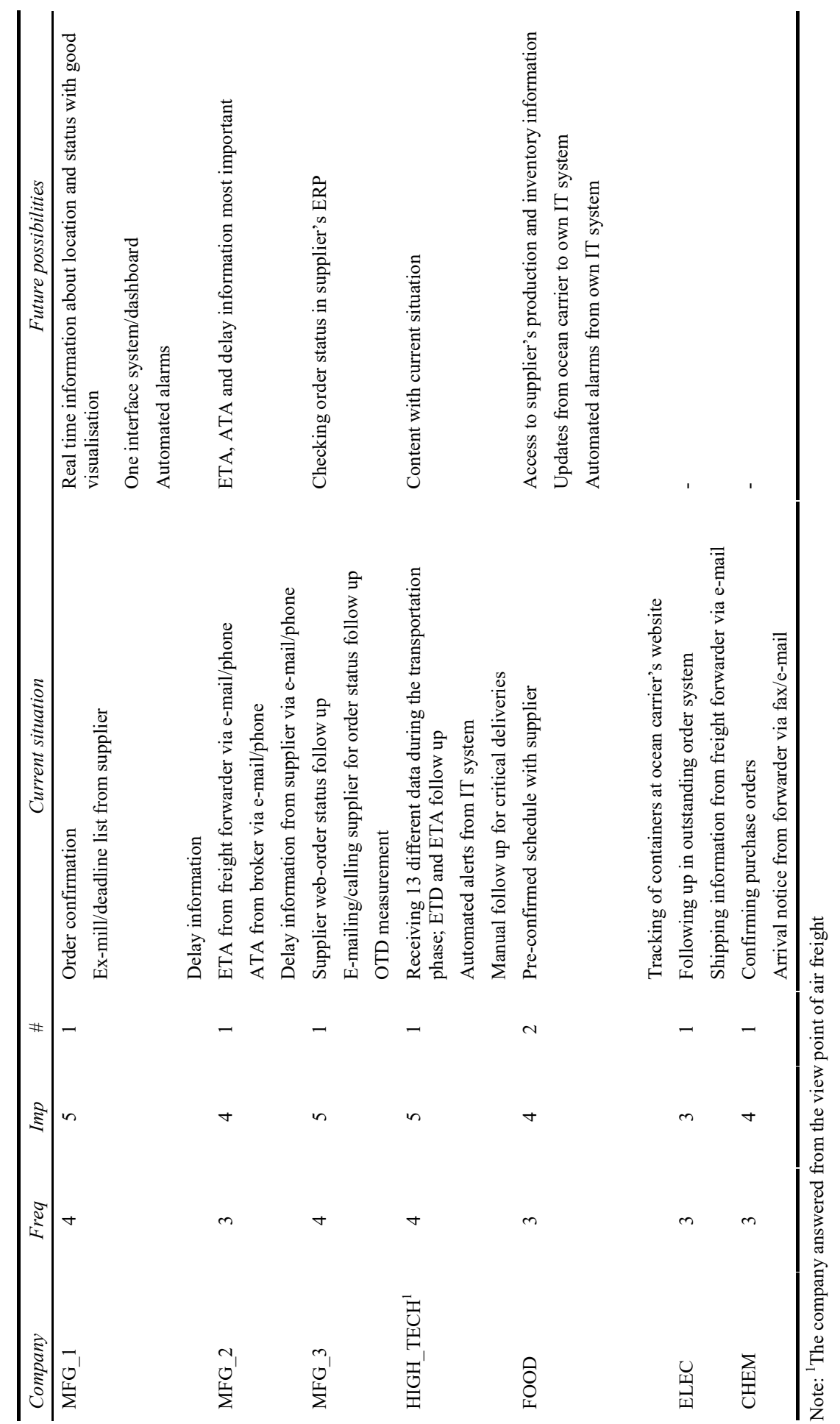


As for information sharing in general, the supplier has an important role and most companies reported that they use information received from the supplier in monitoring late deliveries. Information currently received from the supplier concerns pre-confirmed schedules, order confirmations and order status follow-ups. In addition, the companies would like to have information on production and inventory levels at the supplier.

All companies, except for one, reported that they currently follow their deliveries on the way from the supplier to their site via order follow-ups and arrival notices. Data elements mentioned by several companies were for example estimated time of departure (ETD), estimated time of arrival (ETA), and actual time of arrival (ATA). Also delay information was mentioned by several companies. This data is provided by transportation and logistics companies such as freight forwarders, ocean carriers and brokers. For the future several of the companies wished for more up-to-date time data, i.e. real time information through automated updates. It is apparent that time stamps are among the most important information the companies use for monitoring late deliveries; for example, one of the manufacturing companies sees ETA, ATA and delay information as the most important information they would like to receive also in the future.

Besides information received from other actors in the supply chain, several companies also reported that they follow up on late deliveries in-house by checking on outstanding deliveries or with on-time-delivery (OTD) measurement. One of the companies explained they use OTD data for statistics and feedback.

For the future, a couple of the companies did not express any opinions, and one of the companies stated they are satisfied with how they currently monitor their deliveries. At the same time other companies envisioned sophisticated systems with automated updates, real time information and automated alarms and rescheduling. As one of the respondents put it:

"I would like to see in real time and with good visualization where our goods are and in which amount. A one interface for all information would be a best solution."

Despite seeing benefits with improved information sharing and wishing for more developed information exchange, another respondent still highlighted possible problems that could arise from it:

"I would love to see a cheap system whereby our IT system could be automatically updated with ocean carrier ETS, ETA and container status updates, but there'd need to be some assurance that the information is correct under some penalty to the ocean carrier as a service provider supplying the information if the information is grossly incorrect."

\subsection{TOPSIS analysis}

Results of the TOPSIS approach are reported in Table 5, where the different sources of risks are ranked according to the calculated closeness index. 
Table 5 TOPSIS results

\begin{tabular}{lccccc}
\hline & Frequency & Impact & Risk score & $\begin{array}{c}\text { Closeness } \\
\text { index }\end{array}$ & Ranking \\
\hline Weights & 0.3 & 0.3 & 0.4 & & \\
Sub quality & 0.0116 & 0.0102 & 0.0057 & 0.58 & 2 \\
Wrong product & 0.0087 & 0.0099 & 0.0041 & 0.41 & 6 \\
Late delivery & 0.0174 & 0.0090 & 0.0075 & 0.91 & 1 \\
Damaged goods & 0.0116 & 0.0090 & 0.0050 & 0.53 & 3 \\
Under quantity & 0.0109 & 0.0075 & 0.0039 & 0.40 & 7 \\
Wrong place & 0.0076 & 0.0075 & 0.0027 & 0.25 & 10 \\
Wrong info & 0.0131 & 0.0063 & 0.0040 & 0.48 & 4 \\
Missing info & 0.0109 & 0.0063 & 0.0033 & 0.33 & 8 \\
Exceeding costs & 0.0131 & 0.0060 & 0.0038 & 0.46 & 5 \\
Over quantity & 0.0109 & 0.0045 & 0.0024 & 0.25 & 9 \\
Early delivery & 0.0109 & 0.0039 & 0.0020 & 0.24 & 11 \\
\hline
\end{tabular}

Results are slightly different if compared with the risk analysis. While late deliveries are still ranked at the first place, the following risk sources are in order sub-quality (2), damaged goods (3) and wrong information (4). On the other hand, the risk sources that ranked at the last place are under quantity (7), missing info (8), over quantity (9), wrong place (10) and early deliver at the last place (11).

\section{Discussion}

Late deliveries ranked high on both frequency and impact, and were identified by all companies to be among their most important problems. Still, it is important to bear in mind that risks can seldom be separated from each other, but are on the contrary often interlinked. As Pfohl et al. (2010) and Jüttner et al. (2003) have pointed out, risks can be seen both as sources and as consequences. Taking into account how risk is defined in this study (as a deviation to an ideal state), one consequence, for example a delivery to the wrong place, could at the same time be the source for another deviation, for example a late delivery. A delivery to the wrong place could in turn be due to the delivery having wrong or missing information. Late deliveries might on the other hand cause exceeding costs if the goods then have to be transported using air and not ocean freight. Wrong or missing information could also cause delays at the border, leading to late deliveries. These inter-linkages are though not possible to identify directly based on the answers in this study; for example, one company which ranks late deliveries as frequent still rank exceeding costs only as rare, whereas another company states deliveries to the wrong place are very rare, but late deliveries still frequent. The impact of wrong or missing information ranks as medium, even though one could assume it could cause a lot of other problems.

It is worth noting that the most important risks - late deliveries, sub-quality deliveries, deliveries with damaged goods, and wrong product deliveries - all are risks which, if realised, directly lead to delay in production and/or require the company to keep 
safety stock. Respectively, early deliveries and over quantity deliveries, which do not directly delay production, ranked the lowest. Related to this, some respondents pointed out that they monitor stock levels in order to manage their inbound logistics risks. This interestingly links to the fact that most of the companies ranked supply risk as their most important risk. If inbound logistics risks, as defined in this study, lead to the goods not being at the right place, at the right time, in the right condition and in the right amount, one could actually say the company faces a supply problem, and not an operational problem - even though the supply problem originates in an operational problem.

As it was found in this study, quality is an issue that cannot be overlooked, especially in the food industry; history shows that quality problems in food supply chains have led even to bankruptcies. As a supply chain manager in a report on risks in the food supply chain by Peck (2006) states: quality must always override cost at each time. Still, the food company sees some serious barriers in improving information sharing especially with ocean carriers. Even though technology exists for having data on location, cargo temperature, tilt, vibration, intrusion detection, etc., of the goods while in transit, and the ocean carrier in fact collects all this information, they are unwilling to share this information with the buyer. I've even offered to pay a nominal fee for the container temperature data they are already recording, but not a single carrier was interested; carriers simply aren't interested in letting shippers know too much about their cargo. An additional issue raised by one company concerns the sharing of liabilities as established in the Incoterms, which allow the carriers to take no responsibility for any problems: Sorry, our fault, but per the back of the OBL we can't be held responsible for anything...not even our own human errors... thank you for shipping with us.

An interesting point emerging in the answers was the role and importance of in-house information in monitoring inbound logistics risks. The companies reported that they follow outstanding orders, check for the right products being delivered, test quality, check documents, etc., of incoming goods. With these procedures problems are noticed only when risk have already realised. Even though improved visibility wouldn't eliminate all problems, improved information sharing and the possibility to check much of this information earlier on in the supply chain would give the companies more time to react, cope with and prevent risks from realising.

The only company which reported a high degree of sophistication in monitoring deliveries was the high tech company. It should still be noted here that this company uses air freight and not ocean freight for their deliveries; the difference could have its origin in the transportation mode as different modes have different requirements and practices. The choice of transportation mode is of course also linked to the type of product, and the difference could also have its origin in this as high tech products with high value could require close monitoring in the supply chain.

\section{Conclusions}

Companies that joined this study faced several different problems related to their inbound logistics, of which late deliveries were the most important. All companies except for the food company ranked late deliveries as their most important problem. For the food company quality was a risk that could not be overlooked. Also sub-quality deliveries, wrong product deliveries and under-quantity deliveries ranked high for all companies, but were not as frequent as late deliveries. Information sharing related to inbound logistics 
risk was reported to take place mainly between the buyer and the seller, and regarding late deliveries and sub-quality deliveries also between the buyer and logistics parties. Data shared included order confirmations, order follow-ups and time stamps. Also data collected in-house, such as outstanding orders and quality testing, had an important role in managing inbound logistics risk. The role of technology in providing visibility varied between the companies, but for the moment much of the reported information exchange was manual. For the future some of the companies envisioned sophisticated information systems with automated information exchange and alerts, but other companies had no comments at all.

In this study, much of the current information sharing was reported to take place between the buyer and the seller. Information sharing between these parties has been widely studied for example related to point-of-sales data sharing (POS), vendor managed inventory (VMI) and collaborative planning, forecasting and replenishment (CPFR), which all address problems related to demand and supply. However, the importance of information sharing also with logistics parties has been pointed out in some studies related to the Bullwhip effect. In addition to addressing the amplification of demand as a forecasting problem due to poor communication on demand between buyers and seller, it has been claimed that transportation delays or poor communication between supply chain actors - including transportation parties - could trigger the Bullwhip effect because of variability in lead times and batch sizes. Information sharing with logistics parties was reported by the companies only for late deliveries and to some extent sub-quality deliveries. Regarding late deliveries, it is apparent that tracking of deliveries using for example time stamps and delay information is important, and it was also within this field that the companies wished to develop information sharing. This could thus be a fruitful area to continue the development of information sharing in the logistics chain.

When it comes to sub-quality deliveries and deliveries with damaged goods, only two of the companies mentioned the role of transportation and logistics. Hence, for the majority of the companies, quality was apparently mostly seen as a problem that originates at the seller, and not as much because of wrong handling or wrong transportation conditions. The two companies which mentioned the role of transportation in managing sub-quality and damaged goods were the food company and the high tech company. As the other companies procure more bulk type of goods the nature of the goods procured could thus be assumed to have an impact on this.

The high tech industry is characterised by high-value consumer goods. In addition to causing a direct financial loss, damaged goods that reach the end consumers could have an important reputational impact on the company. In this study, the high tech company reported that they map the flow of their goods in cooperation with the logistics service provider in order to minimise the number of touch points and through that the risk of damage on the goods.

The companies in this study showed great differences in their wishes for how to develop information sharing in the supply chain. Some respondents had clear visions for sophisticated, automated systems, whereas others expressed no wishes at all. The reasons for this could be several, but it could simply be that only those who had given the question of improved visibility a thought earlier had concrete ideas of what it could mean. It is easy to talk about improved visibility in general, but giving concrete ideas on data and technologies is another question. The industry could of course always have its role in this, but both a company procuring mainly bulk as well as companies procuring more valuable products envisioned sophisticated IT systems for information sharing. 
Understanding the reasons for why certain companies or industries look for or invest in improved information sharing would be of greatest interest in future research.

This study focused only on the commercial supply chain, meaning information exchange with customs and other governmental organisations was not included. Still, the wish for improved information sharing with this type of third parties appeared in the answers, indicating information sharing with parties outside the commercial chain could be a focus for improvement as well. This study neither considered in-house information sharing, which is even seen as a pre-requisite for information sharing with supply chain partners by some authors (Frohlich and Westbrook, 2001). In addition, information sharing was only studied related to the companies' most important inbound logistics problems, which means the study did not cover the information sharing taking part exhaustively.

\section{References}

Agndal, H. and Nilsson, U. (2008) 'Supply chain decision-making supported by an open books policy', International Journal of Production Economics, Vol. 116, No. 1, pp.154-167.

Barratt, M. and Oke, A. (2007) 'Antecedents of supply chain visibility in retail supply chains: a resource-based theory perspective', Journal of Operations Management, Vol. 25, No. 6, pp.1217-1233.

Blome, C. and Schoenherr, T. (2011) 'Supply chain risk management in financial crises A multiple case-study approach', International Journal of Production Economics, Vol. 134, No. 1, pp.43-57.

Cantor, D.E. and MacDonald, J.R. (2009) 'Decision-making in the supply chain: examining problem solving approaches and information availability', Journal of Operations Management, Vol. 27, No. 3, pp.220-232.

Chopra, S. and Sodhi, M. (2012) 'Managing risk to avoid supply-chain breakdown', MIT Sloan Management Review, (Fall 2004).

Christopher, M. and Lee, H. (2004) 'Mitigating supply chain risk through improved confidence', International Journal of Physical Distribution \& Logistics Management, Vol. 34, No. 5, pp.388-396.

Dwayne Whitten, G., Green Jr., K.W. and Zelbst, P.J. (2012) ‘Triple-A supply chain performance', International Journal of Operations \& Production Management, Vol. 32, No. 1, pp.28-48.

Fan, H., Li, G., Sun, H. and Cheng, T. (2016) 'An information processing perspective on supply chain risk management: antecedents, mechanism, and consequences', International Journal of Production Economics, March, Vol. 185, pp.63-75.

Flynn, B.B., Huo, B. and Zhao, X. (2010) 'The impact of supply chain integration on performance: a contingency and configuration approach', Journal of Operations Management, Vol. 28, No. 1, pp.58-71.

Frohlich, M.T. and Westbrook, R. (2001) 'Arcs of integration: an international study of supply chain strategies', Journal of Operations Management, Vol. 19, No. 2, pp.185-200.

Gunasekaran, A., Patel, C. and McGaughey, R.E. (2004) 'A framework for supply chain performance measurement', International Journal of Production Economics, Vol. 87, No. 3, pp.333-347.

Harland, C., Brenchley, R. and Walker, H. (2003) 'Risk in supply networks', Journal of Purchasing and Supply Management, Vol. 9, No. 2, pp.51-62.

Hoyt, J. and Huq, F. (2000) 'From arms-length to collaborative relationships in the supply chain: an evolutionary process', International Journal of Physical Distribution \& Logistics Management, Vol. 30, No. 9, pp.750-764. 
Huan, S.H., Sheoran, S.K. and Wang, G. (2004) 'A review and analysis of supply chain operations reference (SCOR) model', Supply Chain Management: An International Journal, Vol. 9, No. 1, pp.23-29.

Jayaram, J. and Tan, K-C. (2010) 'Supply chain integration with third-party logistics providers', International Journal of Production Economics, Vol. 125, No. 2, pp.262-271.

Johnson, M.E. (2001) 'Learning from toys: lessons in managing supply chain risk from the toy industry', California Management Review, Vol. 43, No. 3, pp.106-124.

Jüttner, U. (2005) 'Supply chain risk management: understanding the business requirements from a practitioner perspective', The International Journal of Logistics Management, Vol. 16, pp.120-141.

Jüttner, U., Peck, H. and Christopher, M. (2003) 'Supply chain risk management: outlining an agenda for future research', International Journal of Logistics: Research and Applications, Vol. 6, No. 4, pp.197-210.

Koçoğlu, İ., İmamoğlu, S.Z., İnce, H. and Keskin, H. (2011) 'The effect of supply chain integration on information sharing: enhancing the supply chain performance', Procedia-Social and Behavioral Sciences, Vol. 24, pp.1630-1649.

Lee, H.L. (2004) 'The triple-A supply chain', Harvard Business Review, Vol. 82, No. 10, pp.102-113.

Lee, H.L. and Whang, S. (2005) 'Higher supply chain security with lower cost: lessons from total quality management', International Journal of Production Economics, Vol. 96, No. 3, pp.289-300.

Li, S., Rao, S.S., Ragu-Nathan, T. and Ragu-Nathan, B. (2005) 'Development and validation of a measurement instrument for studying supply chain management practices', Journal of Operations Management, Vol. 23, No. 6, pp.618-641.

Lockamy III, A. and McCormack, K. (2009) 'Examining operational risks in supply chains', Supply Chain Forum, Vol. 10, No. 1, pp.2-14.

Manuj, I. and Mentzer, J.T. (2008) 'Global supply chain risk management strategies', International Journal of Physical Distribution \& Logistics Management, Vol. 38, No. 3, pp.192-223.

McGillivray, G. (2000) 'Commercial risk under JIT', Canadian Underwriter, Vol. 67, No. 1, pp.26-30.

Mobin, M. and Roshani, A. (2016) 'An integrated approach for ranking supplier evaluation criteria (Case study: a construction project-based company)', Proceedings of the American Society for Engineering Management 2016 International Annual Conference, S. Long, E-H. Ng, C. Downing and B. Nepal (Eds.).

Mousavi, S.M. and Pasandideh, S.H. (2011) 'A multi-periodic multi-product inventory control problem with discount: GA optimization algorithm', Journal of Optimization in Industrial Engineering, Vol. 4, No. 7, pp.37-44.

Mousavi, S.M., Sadeghi, J., Niaki, S.T.A. and Tavana, M. (2016) 'A bi-objective inventory optimization model under inflation and discount using tuned Pareto-based algorithms: NSGA-II, NRGA, and MOPSO', Applied Soft Computing, Vol. 43, pp.57-72.

Peck, H. (2006) 'Reconciling supply chain vulnerability, risk and supply chain management', International Journal of Logistics: Research and Applications, Vol. 9, No. 2, pp.127-142.

Pfohl, H-C., Köhler, H. and Thomas, D. (2010) 'State of the art in supply chain risk management research: empirical and conceptual findings and a roadmap for the implementation in practice', Logistics Research, Vol. 2, No. 1, pp.33-44.

Sadeghi, J., Mousavi, S.M., Niaki, S.T.A. and Sadeghi, S. (2013) 'Optimizing a multi-vendor multi-retailer vendor managed inventory problem: two tuned meta-heuristic algorithms', Knowledge-Based Systems, Vol. 50, pp.159-170.

Salmon, C., Mobin, M. and Roshani, A. (2015) 'TOPSIS as a method to populate risk matrix axes', Proceedings IIE Annual Conference, Institute of Industrial Engineers-Publisher, pp.1504-1513. 
Sanchez Rodrigues, V., Stantchev, D., Potter, A., Naim, M. and Whiteing, A. (2008) 'Establishing a transport operation focused uncertainty model for the supply chain', International Journal of Physical Distribution \& Logistics Management, Vol. 38, No. 5, pp.388-411.

Schwab, K. (2012) The Global Competitiveness Report 2012-2013, World Economic Forum, Geneva, Switzerland.

Sezen, B. (2008) 'Relative effects of design, integration and information sharing on supply chain performance', Supply Chain Management: An International Journal, Vol. 13, No. 3, pp. 233-240.

Sheffi, Y. and Rice Jr., J.B. (2005) 'A supply chain view of the resilient entreprise', MIT Sloan Management Review, Vol. 47, No. 1.

Sodhi, M.S., Son, B.G. and Tang, C.S. (2012) 'Researchers' perspectives on supply chain risk management', Production and Operations Management, Vol. 21, No. 1, pp.1-13.

Svensson, G. (2002) 'A conceptual framework of vulnerability in firms' inbound and outbound logistics flows', International Journal of Physical Distribution \& Logistics Management, Vol. 32, No. 2, pp.110-134.

Tatoglu, E., Bayraktar, E., Golgeci, I., Koh, S.L., Demirbag, M. and Zaim, S. (2016) 'How do supply chain management and information systems practices influence operational performance? Evidence from emerging country SMEs', International Journal of Logistics Research and Applications, Vol. 19, No. 3, pp.181-199.

Tzeng, G-H. and Huang, J-J. (2011) Multiple Attribute Decision Making: Methods and Applications, CRC Press, Boca Raton, FL.

Urciuoli, L. (2016) 'What are the causes of transport insecurity? Results from a survey with transport operators', Transport Policy, Vol. 47, pp.189-202.

Urciuoli, L. and Hintsa, J. (2016) 'Differences in security risk perceptions between logistics companies and cargo owners', The International Journal of Logistics Management, Vol. 27, No. 2, pp.418-437.

Vanderhaeghe, A. and Treville, S. (2003) 'How to fail at flexibility', Supply Chain Forum - An International Journal, Vol. 4, No. 1, pp.67-73.

Venkatesh, V., Rathi, S. and Patwa, S. (2015) 'Analysis on supply chain risks in Indian apparel retail chains and proposal of risk prioritization model using Interpretive structural modeling', Journal of Retailing and Consumer Services, Vol. 26, pp.153-167.

Viswanadham, N. and Gaonkar, R.S. (2008) 'Risk management in global supply chain networks', Supply Chain Analysis, pp.201-222, Springer, USA.

Wagner, S.M. and Bode, C. (2006) 'An empirical investigation into supply chain vulnerability', Journal of Purchasing and Supply Management, Vol. 12, No. 6, pp.301-312.

Yin, R.K. (2014) Case Study Research: Design and Methods, (Applied Social Research Methods), Vol. 5, 5th ed., Sage Publications Inc., London, UK. 


\section{Appendix}

Dear receiver,

We would like to kindly ask you to fill in this survey about inbound logistics risks in your supply chain. This survey has been developed by the XXX within a research project financed by the Seventh Framework Programme (FP7), XXX. The purpose of this survey is to understand how companies are monitoring and mitigating risks related to their inbound logistics, and how companies are exchanging information for risk managing purposes.

Please answer all questions from your inbound logistics perspective, concentrating on multi-modal and intercontinental shipments that have a maritime leg. If you don't use maritime mode for your shipments, please contact us to agree on another logistics approach. We ask you to consider an average trade lane from 2011 in all questions.

In the first part of the questionnaire we ask you to assess different logistics problems in your supply chain. In the second part we ask you how you monitor these problems. Finally we ask for your opinion on information sharing between supply chain actors for risk managing purposes.

The survey should take around 30 minutes to complete. All answers will be kept confidential. As a thanks for your contribution we will send an executive summary of the survey's results (please specify your email address in the questionnaire).

The survey can be handed in either by filling in the questionnaire as a Word document and sending it to email address here, or by printing the questionnaire and sending the completed form by fax to $<$ fax number $>$ (or as a scanned copy by e-mail).

You are welcome to contact us for any further questions.

Thank you for your help!

\section{Background information}

Please fill in some background information below. The e-mail address will only be used for sending a copy of the executive summary, and will be separated from all analysis.

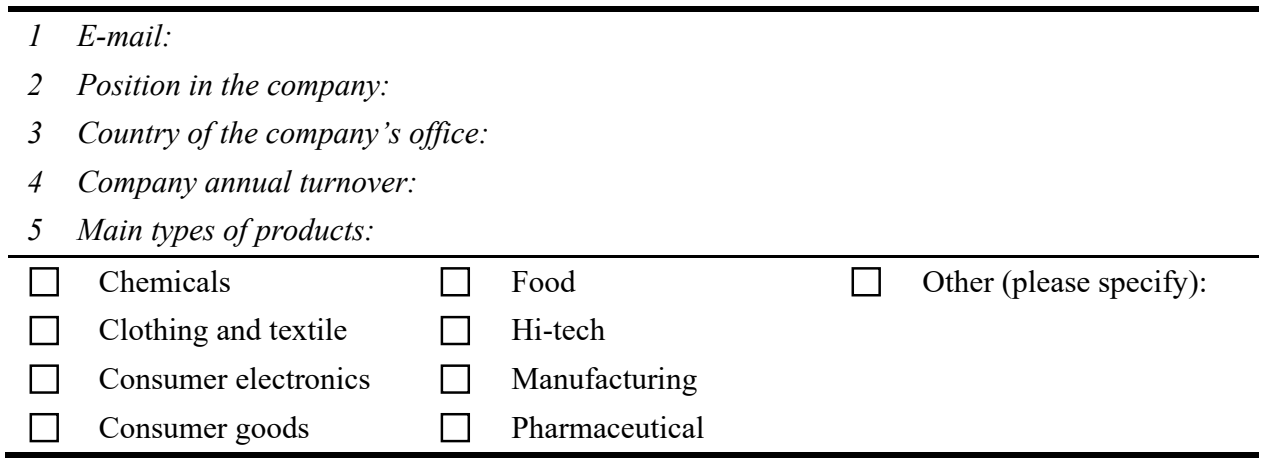




\section{A Identifying your logistics problems}

In this part we ask you to assess the frequency and impact of different problems related to your inbound logistics, and to identify the three most important problems your company faces.

\begin{tabular}{|c|c|c|c|c|c|c|}
\hline \multicolumn{7}{|l|}{$\begin{array}{ll}6 & \text { How wo } \\
\text { chain? }\end{array}$} \\
\hline & $\begin{array}{l}\text { Very } \\
\text { rare }\end{array}$ & Rare & Occasional & Frequent & $\begin{array}{c}\text { Very } \\
\text { frequent }\end{array}$ & $\begin{array}{l}\text { Cannot } \\
\text { say }\end{array}$ \\
\hline Late deliveries & $\square$ & $\square$ & $\square$ & $\square$ & $\square$ & $\square$ \\
\hline Early deliveries & $\square$ & $\square$ & $\square$ & $\square$ & $\square$ & $\square$ \\
\hline $\begin{array}{l}\text { Under quantity } \\
\text { deliveries }\end{array}$ & $\square$ & $\square$ & $\square$ & $\square$ & $\square$ & $\square$ \\
\hline $\begin{array}{l}\text { Over quantity } \\
\text { deliveries }\end{array}$ & $\square$ & $\square$ & $\square$ & $\square$ & $\square$ & $\square$ \\
\hline $\begin{array}{l}\text { Wrong product } \\
\text { deliveries }\end{array}$ & $\square$ & $\square$ & $\square$ & $\square$ & $\square$ & $\square$ \\
\hline $\begin{array}{l}\text { Sub-quality } \\
\text { deliveries }\end{array}$ & $\square$ & $\square$ & $\square$ & $\square$ & $\square$ & $\square$ \\
\hline $\begin{array}{l}\text { Deliveries with } \\
\text { damaged goods }\end{array}$ & $\square$ & $\square$ & $\square$ & $\square$ & $\square$ & $\square$ \\
\hline $\begin{array}{l}\text { Deliveries to wrong } \\
\text { place }\end{array}$ & $\square$ & $\square$ & $\square$ & $\square$ & $\square$ & $\square$ \\
\hline $\begin{array}{l}\text { Actual delivery } \\
\text { cost exceeds } \\
\text { planned cost }\end{array}$ & $\square$ & $\square$ & $\square$ & $\square$ & $\square$ & $\square$ \\
\hline $\begin{array}{l}\text { Deliveries with } \\
\text { wrong } \\
\text { documentation or } \\
\text { data }\end{array}$ & $\square$ & $\square$ & $\square$ & $\square$ & $\square$ & $\square$ \\
\hline $\begin{array}{l}\text { Deliveries with } \\
\text { missing } \\
\text { documentation or } \\
\text { data }\end{array}$ & $\square$ & $\square$ & $\square$ & $\square$ & $\square$ & $\square$ \\
\hline $\begin{array}{l}\text { Other } \\
\text { (please specify): }\end{array}$ & $\square$ & $\square$ & $\square$ & $\square$ & $\square$ & $\square$ \\
\hline
\end{tabular}


7 How would you assess the financial impact of the following logistics problems? Please do not take into account the frequency of the problem when assessing the impact, but assess the impact resulting from problems with one delivery being e.g. late.

\begin{tabular}{|c|c|c|c|c|c|c|}
\hline & $\begin{array}{l}\text { Insignificant } \\
\text { impact }\end{array}$ & $\begin{array}{l}\text { Low } \\
\text { impact }\end{array}$ & $\begin{array}{l}\text { Medium } \\
\text { impact }\end{array}$ & $\begin{array}{l}\text { High } \\
\text { impact }\end{array}$ & $\begin{array}{c}\text { Very } \\
\text { high } \\
\text { impact }\end{array}$ & $\begin{array}{l}\text { Cannot } \\
\text { say }\end{array}$ \\
\hline Late deliveries & $\square$ & $\square$ & $\square$ & $\square$ & $\square$ & $\square$ \\
\hline Early deliveries & $\square$ & $\square$ & $\square$ & $\square$ & $\square$ & $\square$ \\
\hline $\begin{array}{l}\text { Under quantity } \\
\text { deliveries }\end{array}$ & $\square$ & $\square$ & $\square$ & $\square$ & $\square$ & $\square$ \\
\hline $\begin{array}{l}\text { Over quantity } \\
\text { deliveries }\end{array}$ & $\square$ & $\square$ & $\square$ & $\square$ & $\square$ & $\square$ \\
\hline $\begin{array}{l}\text { Wrong product } \\
\text { deliveries }\end{array}$ & $\square$ & $\square$ & $\square$ & $\square$ & $\square$ & $\square$ \\
\hline $\begin{array}{l}\text { Sub-quality } \\
\text { deliveries }\end{array}$ & $\square$ & $\square$ & $\square$ & $\square$ & $\square$ & $\square$ \\
\hline $\begin{array}{l}\text { Deliveries with } \\
\text { damaged goods }\end{array}$ & $\square$ & $\square$ & $\square$ & $\square$ & $\square$ & $\square$ \\
\hline $\begin{array}{l}\text { Deliveries to wrong } \\
\text { place }\end{array}$ & $\square$ & $\square$ & $\square$ & $\square$ & $\square$ & $\square$ \\
\hline $\begin{array}{l}\text { Actual delivery } \\
\text { cost exceeds } \\
\text { planned cost }\end{array}$ & $\square$ & $\square$ & $\square$ & $\square$ & $\square$ & $\square$ \\
\hline $\begin{array}{l}\text { Deliveries with } \\
\text { wrong } \\
\text { documentation or } \\
\text { data }\end{array}$ & $\square$ & $\square$ & $\square$ & $\square$ & $\square$ & $\square$ \\
\hline $\begin{array}{l}\text { Deliveries with } \\
\text { missing } \\
\text { documentation or } \\
\text { data }\end{array}$ & $\square$ & $\square$ & $\square$ & $\square$ & $\square$ & $\square$ \\
\hline $\begin{array}{l}\text { Other } \\
\text { (please specify): }\end{array}$ & $\square$ & $\square$ & $\square$ & $\square$ & $\square$ & $\square$ \\
\hline $8 \begin{array}{l}\text { Please identify y } \\
\text { based on your as } \\
\text { important risk, } 2\end{array}$ & $\begin{array}{l}r \text { three most in } \\
\text { ssments in que } \\
\text { eing the seconc }\end{array}$ & $\begin{array}{l}\text { rtant in } \\
\text { ons } 6 \text { ar } \\
\text { ost imp }\end{array}$ & $\begin{array}{l}\text { und logist } \\
\text { 7, and list } \\
\text { tant risk, e }\end{array}$ & $\begin{array}{l}\text { problem } \\
\text { im below } \\
\text { : }\end{array}$ & $\begin{array}{l}\text { frequen } \\
\text { being the }\end{array}$ & $\begin{array}{l}\times \text { impact } \\
\text { ost }\end{array}$ \\
\hline \multicolumn{7}{|l|}{1} \\
\hline \multicolumn{7}{|l|}{2} \\
\hline 3 & & & & & & \\
\hline
\end{tabular}




\section{B Monitoring and mitigating risks through risk rules}

In this section we ask about risk rules that you use for monitoring and mitigating the risks identified in question 8 . With a risk rule we mean a rule or regulation that you follow in order to enhance secure, smooth and efficient operations of the supply chain. A risk rule differs from risk management in that it sets standard operation procedures for how to act, whereas risk management requires assessing the risk separately for each individual situation. An example of a risk rule would be requiring drivers to take a break after four hours of driving - then the driver doesn't need to assess himself whether he is too tired to continue driving safely or not.

Risk rules can be used either to prevent a problem from happening (e.g. to keep the temperature between 2 and $8^{\circ} \mathrm{C}$ for a certain type of goods), to define when to react on a problem (e.g. to take action if the temperature falls below $2^{\circ} \mathrm{C}$ in the storage), or to define actions to take when a problem is detected (e.g. to make an additional quality check if temperature has fallen below $2^{\circ} \mathrm{C}$ ). Risk rules can be either legislative regulations (e.g. to treat dangerous goods in a certain way) or 'self-invented' within the company (e.g. to call the supplier if a delivery is more than 2 hours late).

Please answer the questions below about risk rules for each of the three most important inbound logistics problems you identified in question 8 .

\begin{tabular}{ll}
\hline 9 & Most important problem: Sub quality deliveries \\
\hline a) & What are the three most important risk rules that you use to monitor/mitigate this problem? \\
\hline 1 & \\
2 & \\
3 & \\
\hline b) & For these rules, how do you identify that something is going wrong or that actions are \\
& needed? (e.g. by following manually, receiving an alert from an IT-system) \\
\hline 1 & \\
2 & \\
3 & \\
\hline$c)$ & If you had better access to information in the supply chain, which three rules would you like \\
to use to better monitor/mitigate this problem? \\
\hline 1 & \\
2 & \\
3 & \\
\hline d) & For these proposed rules, how would you like to identify that something is going wrong or \\
that actions are needed? (e.g. by following manually, receiving an alert from an IT-system)
\end{tabular}




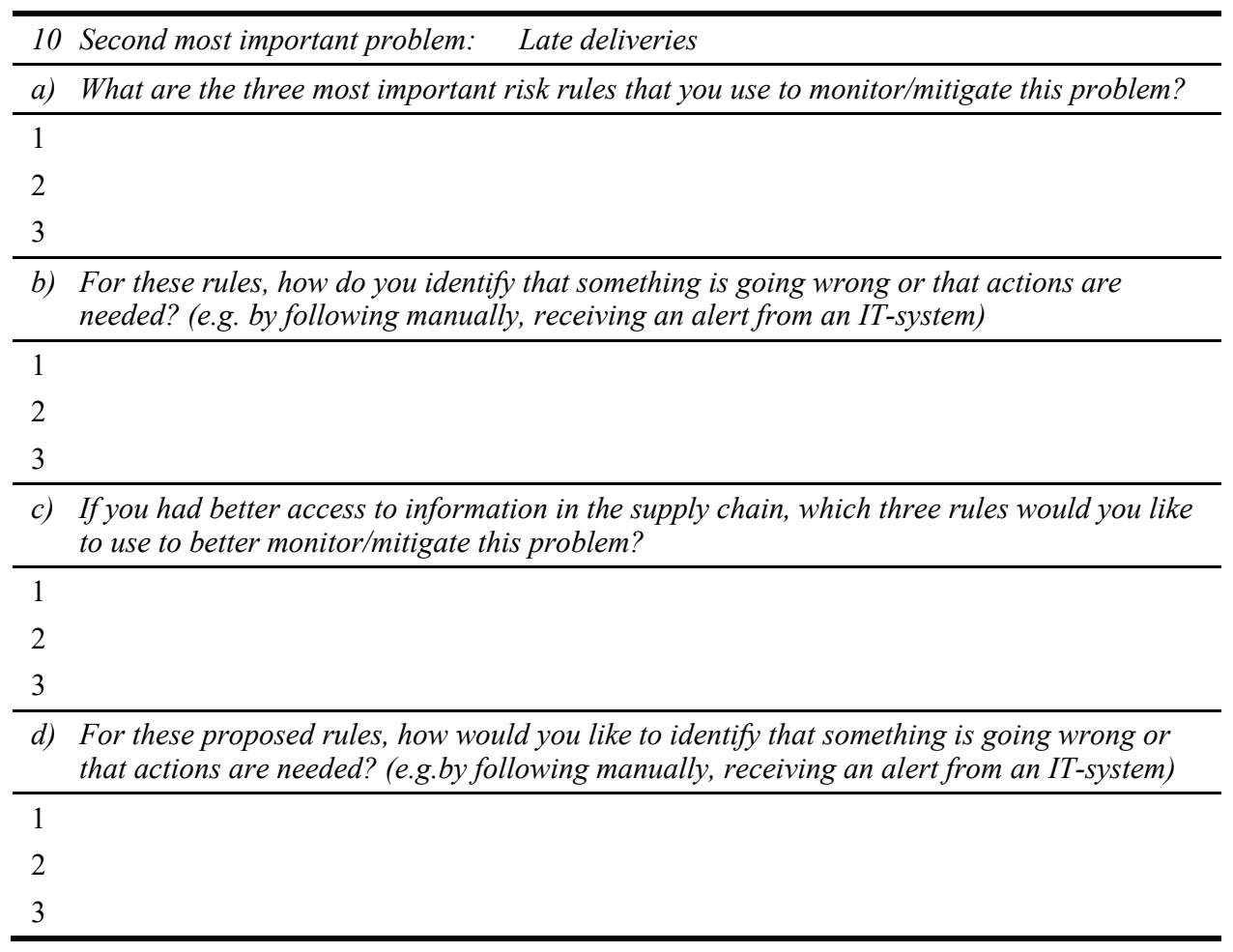

\begin{tabular}{ll}
\hline 11 & Third most important problem: Deliveries with missing documentation or data \\
\hline a) & What are the three most important risk rules that you use to monitor/mitigate this problem? \\
\hline 1 & \\
2 & \\
3 & \\
\hline b) & For these rules, how do you identify that something is going wrong or that actions are \\
& needed? (e.g. by following manually, receiving an alert from an IT-system) \\
\hline 1 & \\
2 & \\
3 & \\
\hline$c)$ & If you ha better access to information in the supply chain, which three rules would you like \\
& to use to better monitor/mitigate this problem? \\
\hline 1 & \\
2 & \\
3 & \\
\hline$d)$ & For these proposed rules, how would you like to identify that something is going wrong or \\
& that actions are needed? (e.g. by following manually, receiving an alert from an IT-system) \\
\hline 1 & \\
2 & \\
3 &
\end{tabular}




\section{Information sharing with supply chain actors}

In this section we ask about how enhanced information sharing with another supply chain actor could help you better monitor/mitigate the three most important inbound logistics problems identified in question 8 .

12 Who is the single most important actor in your supply chain with whom you would like to enhance information sharing, in order to better monitor/mitigate the three most important inbound logistics problems identified in question 8 ?

\begin{tabular}{|c|c|}
\hline Seller & $\square$ \\
\hline Freight forwarder & $\square$ \\
\hline Logistics service provider (3PL) & $\square$ \\
\hline Container depot operator (country of origin) & $\square$ \\
\hline Inland carrier (country of origin) & $\square$ \\
\hline Sea terminal operator (country of origin) & $\square$ \\
\hline Shipping line/sea carrier & $\square$ \\
\hline Sea terminal operator (country of destination) & $\square$ \\
\hline Inland carrier (country of destination) & $\square$ \\
\hline Inland terminal operator (country of destination) & $\square$ \\
\hline Empty container depot operator (country of destination) & $\square$ \\
\hline Other party (please specify): & $\square$ \\
\hline \multicolumn{2}{|c|}{$\begin{array}{l}13 \text { Which are the three most important data elements or pieces of information that you receive } \\
\text { from this actor at the moment that help you monitor/mitigate your three most important } \\
\text { inbound logistics problems? }\end{array}$} \\
\hline \multicolumn{2}{|l|}{1} \\
\hline \multicolumn{2}{|l|}{2} \\
\hline \multicolumn{2}{|l|}{3} \\
\hline \multicolumn{2}{|c|}{$\begin{array}{l}14 \text { How do you receive/get this data or information? (e.g. through EDI, by calling the } \\
\text { company) }\end{array}$} \\
\hline \multicolumn{2}{|l|}{1} \\
\hline \multicolumn{2}{|l|}{2} \\
\hline \multicolumn{2}{|l|}{3} \\
\hline \multicolumn{2}{|c|}{$\begin{array}{l}15 \text { Which would be the three most important data elements or pieces of information you would } \\
\text { like to receive from this actor that would help you better monitor/mitigate your three most } \\
\text { important inbound logistics problems? }\end{array}$} \\
\hline \multicolumn{2}{|l|}{1} \\
\hline \multicolumn{2}{|l|}{2} \\
\hline \multicolumn{2}{|l|}{3} \\
\hline
\end{tabular}



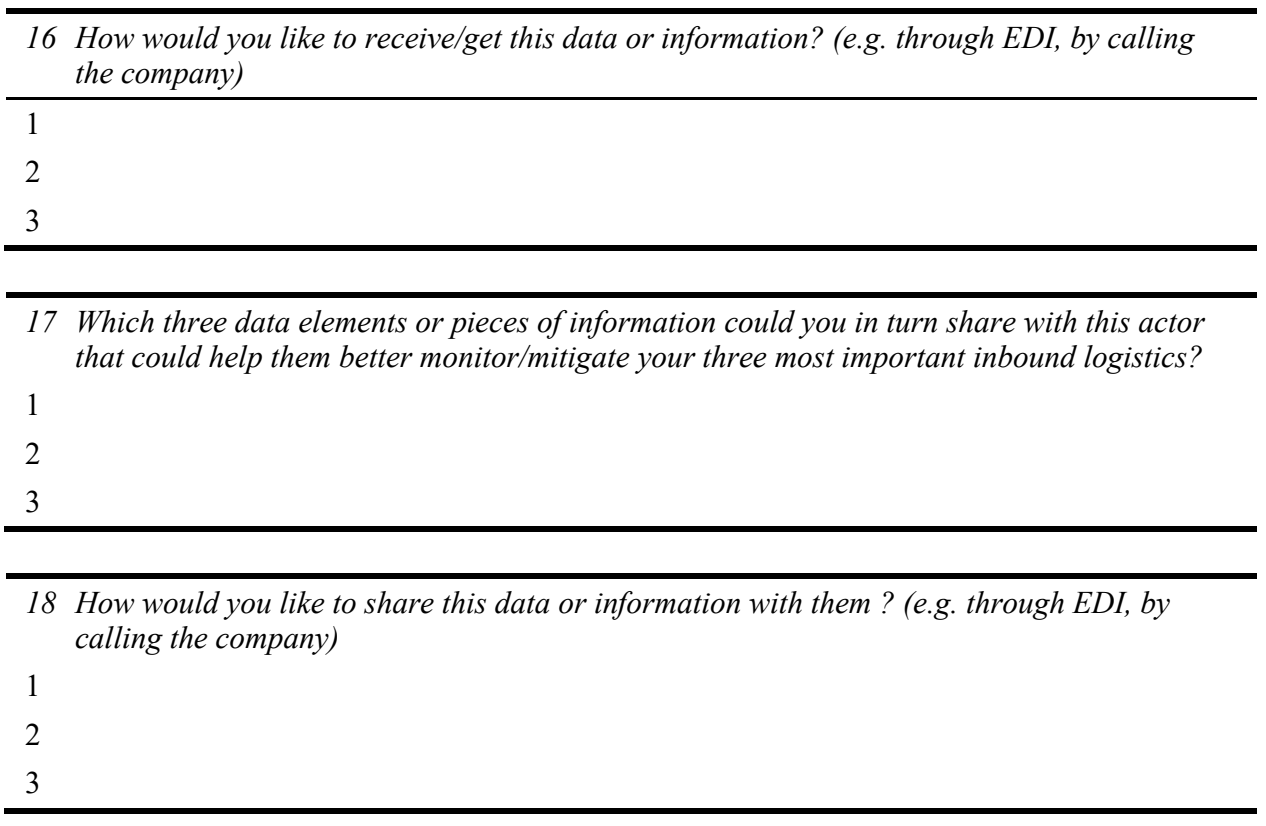

19 Other comments

Thank you! 